\title{
Freedom but Insecurity: the Business Consulting Profession in the Post-Industrial Service Society'
}

I Arja Haapakorpi ${ }^{2}$

Work Research Centre WRC, Tampere University, Finland

\begin{abstract}
In the post-industrial era, the service sector has been expanding and professional tasks have been transformed into service-oriented knowledge work, that is, the business consulting profession. The variety of employment patterns has increased with the deregulation of the labor market, and the employment pattern of those professionals working in the service sector has been characterized by short-term assignments and employment contracts. Despite this contingent employment, the position of the business consulting professionals in the labor market is not necessarily degrading, as they are highly-qualified and competent actors, who can deal with the challenges of the business world. Thus, their position and coping strategies relate not only to the precarious employment but also to their professional, independent work. The study deals with the dilemma of insecurity and freedom of business consulting professionals, which is recognized in the Nordic countries. The methodology is qualitative.
\end{abstract}

\section{KEYWORDS}

Business consulting profession / contingent work / free profession / multiple job holding / post-industrial society / self-employment / service society

\section{Introduction}

dvanced business consulting services are among those industry sectors enjoying substantial growth. The increase in these services is related to overlapping changes in the economy, technology, labor force and the markets, which have been explained by the theories of post-industrialism, post-Fordism and precariousness (Harvey 2005; Standing 2014; Vallas 2017). These theories discuss the trends of the liberalization and deregulation of the labor market, the policy of increasing the flexibility of the labor market, the growth of services and the decline of employment terms. The era of transforming production and employment in a flexible way has been called post-industrial or post-Fordist, the former emphasizing the growth in services and the decline in industrial production, and the latter focusing on new patterns of organizing production and consumption. The post-Fordist approach, in particular, is concerned with the shift from mass production towards flexible specialization and horizontally organized production (Boje \& Furåker 2003; Vallas 2017). For vertically organized production, a relationshiplogic, based on long-term commitment is typical, which is replaced with the transactional contracting of employees, thus resulting in fragmentation of work (Rubery 2015).

The scholars interested in precariousness have analyzed the post-industrial service society in a framework comprising the unstable global economy, the reorganization of

\footnotetext{
${ }^{1}$ You can find this text and its DOI at https://tidsskrift.dk/njwls/index.

${ }^{2}$ Corresponding author: Arja Haapakorpi, Tampere University, Work Research Centre WRC, Kalevantie 5, 33014 Tampere, Finland. E-mail: arja.haapakorpi@tuni.fi, ORCID 0000-001-8847-8073.
} 
the labor force and work, and the growth in precarious employment patterns. These critical scholars claim that liberal ideology is the source of precarious employment (Harvey 2005; Standing 2014). International statistical offices and Finland's statistical office confirm changes in employment patterns, particularly in terms of self-employment (Eurofound 2018; Sutela \& Pärnänen 2018: 11-13). The growth in part-time selfemployment is common in Western Europe and it has been remarkable in Finland and Denmark (OECD 2018: 89; Sutela \& Pärnänen 2018: 11-13). Among the European countries, multiple job holding tends to be highest in the Nordic countries (Pouliakas 2017). The self-employed are strongly polarized into the categories of the low-skilled/ low-waged and professionals with high income levels. However, the position of selfemployed people across nation states is less secure compared to salary-earners, as the former do not usually have access to unemployment benefits (OECD 2018: 89-94).

From the perspective of labor demand, work organizations promote recruitment strategies, which emphasize flexibility in respect of the quantity and quality of the labor force (Boje \& Grönlund 2003; Pfeffer 1994: 22; Vallas 2017). From the labor supply perspective, contingent work, whether demanding or simple, is increasingly offered as a short-term employment contract or self-employment, with a limited number of permanent staff coordinating and managing the basic functions of work organization (Neal \& Morgan 2000).

These labor strategies also apply to a highly-qualified, professional labor force. In addition to 'traditional' business consultants, a variety of expertise is provided as a service, instead of recruiting a professional labor force into stable employment contracts. Professional work in the service industry has been called the 'newest profession', 'advanced business profession' or 'consulting profession', which underlines the fact that the nature of the work is knowledge-based, service-oriented and non-institutionalized (Maestripiere 2016). Business consultant professional services are diverse, covering the fields of counselling, information and communication technologies, HR management, research-focused services, the management of development projects and 'good life and well-being' services (Brint 2001). The business consulting profession is not a solid, uniform group with an institutionalized body of knowledge and related practices and patterns, but a heterogenous and ambiguous field of experts, who are sourced from different disciplines and knowledge fields (Brint 2001; Hurl 2017).

Business consulting professional services are required to complete a specific task which is tied to a relatively short or limited duration. The assignment may also constitute a limited number of working hours over a longer period. This kind of employment pattern is called contingent work. It is related to a variety of employment relations, including self-employed, professional employees in consulting firms or contractors from staffing agencies (Barley \& Kunda 2004, 2006).

The clients of business consulting professionals are private- and public-sector organizations, while subcontracting strategies are broadly applied across society and the markets. Thus, instead of recruiting permanent staff, an assortment of services is required to meet the needs of organizations. The expansion of professional consulting services is recognized in affluent Western countries (Boje 2003); in Finland, the growth of business consulting services has been significant (Statistics Finland 2018).

Studies on the business consultant profession have primarily focused on (1) the growth of consultant services in conjunction with new liberal policies, (2) the need for and utilization of consulting services in companies and (3) the legitimation of business

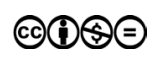


consultants' status and work as a profession. The perspectives of these studies have ranged from practical studies on the flexible utilization of these consultants for organizational purposes (Hurl 2017) to sometimes rather normative discussions concerning the jurisdiction of this group as a profession (Brint 2001) and its legitimating role in undemocratic, political or managerial decisions (McKenna 2006: 231). The position of these consultants in the labor market has not been a popular research field within the sociology of work, although their contingent work can be connected to discussions on self-employment and the increase of non-standard employment. In addition, the statistical evidence and the broad perspective of macro-theoretical conceptions provide a firm perspective on labor market structures and trends, but the coping strategies have not been studied adequately (Atkinson 2007; Vallas 2017).

In terms of the sociology of work, the position of business consulting professionals as a highly qualified labor force in the context of contingent employment is topical; while they may not be precisely classified as a precarious labor force due to their human capital, their position as a contingent labor force implies that what they do is nonstandard work. This article contributes to the understudied field of qualified free professions in the era of the post-industrial service society and deregulated labor market, by studying the business consultant professionals' position and coping methods in the labor market.

The methodological approach is qualitative, and the data come from the research project 'Multiple job holding - practices and institutional frame'. The group of free professionals studied are within the middle-aged category.

The structure of the article is as follows: a discussion on the relevant literature and theory forms the introduction. The first section examines the post-industrial service society and its associated precariousness as a basis for the analysis and maps the research subject in the labor market. Next, the data and methodology, and the research problem and questions are presented. The analysis follows and conclusions section completes the article.

\section{The liberal wave and precariousness: case study of Nordic countries}

Alongside the liberalization wave, the relationship between the labor force and capital has changed, and the employers' position by comparison with employees has strengthened (Vallas 2017). The flexible labor market allows employers to manage growing uncertainty in the markets (Boje \& Grönlund 2003), which applies to workers and professionals in various positions in the labor market (Standing 2014). Guy Standing applies the concept 'neo-liberalism' to describe the opening of economies, firms and individuals to competition, the increasing flexibility in labor markets and the replacement of institutional collective solidarity with individualization and markets (Standing 2014: 32-37). According to Standing (2014), degrading employment terms and permanent uncertainty are the consequences of the wave.

Uncertainty penetrates a variety of practices in employment and working life. First, employment is fragmented into short-term contracts or assignments. Second, nonstandard employment patterns push people out of social benefits, such as unemployment benefits and pension systems. Third, underemployment becomes common with the flexible organization of work (Honkanen 2018; Lorey 2015; Standing 2014: 11). As a consequence, uncertainty penetrates different areas of life. Instead of collective action, 
individualized coping strategies are applied. Subjectivity becomes the means to work on individual 'branding', developing oneself for market-purposes and controlling the uncertainty with individualized methods (Lorey 2015: 70-83). Subjectivity is related to the nature of work in the post-industrial society: service-based work is embedded in the subject and the individual (Lorey 2015: 70-83). Subjectivity may provide a sense of individual freedom or independence, at least for those who cope with the uncertainty and find their niche in the market. For example, Reynolds and Rezulli (2005) report that self-employment may be considered as liberating workers from hierarchies, subordination and the pressuring control of large organizations, typical of the industrial era. According to Lorey (2015: 63-64), the tension of freedom and uncertainty becomes dominating, while in the era of industrial welfare societies, the tension relating to freedom and security is erased.

However, the liberal ideology is applied in various ways across nation states. In Nordic countries, the consequences of the liberal wave have been moderate for historical reasons (Pollitt \& Bouchaert 2004). For these countries, a special welfare regime, based on universalist ideology (Esping-Andersen 1990) and collective labor market agreements (Esping-Andersen 1990; Kettunen 2010), has been typical. The welfare state has guaranteed social security (Esping-Andersen 1990).

A welfare society and collective agreements in the labor market do not exist anymore in their traditional mode and the countries have diverged in relation to their welfare and labor policies, and collective bargaining (Kristiansen 2015). The welfare state has been adjusted to accommodate global economic competition, with the policy of increasing flexibility in the labor market (Einhorn \& Loque 2010). Thelen (2012) describes this adjustment as 'liberalization through what we might think of as socially embedded flexibilization'.

In Finland, the collective bargaining system, based on the tri-partite agreement has been very much in evidence, but during the last decade, it has been declining. In addition, the function of bargaining has been reshaped due to the changes in labor markets and their related employment relations. Instead of solidarity in bargaining, the function has been reduced to controlling the juridical regulations of employment contracts (Ylhäinen 2018). The growing category of self-employees has been excluded from labor market bargaining, which has exposed them to individual contracting (Honkanen 2018).

The growing number and increasing multiplicity of services in business consulting is related to many trends in society, labor market and organization of work. Although Finland as a Nordic country applies regulation on working life, flexibility in labor market, growing service economy, outsourcing and horizontal organization of work foster conditions for contingent employment patterns and the individualization of employment strategies of knowledge workers. With these changes, the profession follows a service-oriented mode of knowledge work, which is discussed in the following section.

\section{The business consulting profession: knowledge work as a service}

According to Brint (2001), the post-industrial economy is based on professionalization; however, the new groupings related to it, fail to comply with the traditional process of professionalization, despite the quality of work involved. The new expert groups go beyond the traditional mode of professionalism (Maestripieri 2016). Thus, although 
these new expert occupations are not socially and culturally accepted as professions, they are required for demanding knowledge-based tasks and roles. Their increasing prevalence in the expert labor market emphasizes the need to study them in a more profound way, rather than simply focusing on their professional legitimation (Brint 2001; Maestripieri 2016).

The business consulting profession lacks clear and solid identification in the form of knowledge bodies, due to the nature of the knowledge and the multiplicity of sources. Consultants' expertise is a convergence of knowledge, applications, experience and problem-solving. According to Hurl (2017), the interaction of business consultant professionals with intra- and inter-organizational knowledge production, forms the basis of their expertise. They source information and knowledge, which are generated in different locations and translate them into a central node, where they can be deployed. The process for providing consulting services involves a mixture of knowledge, expertise and co-solving problems, mediated and circulated through layers of people, texts and technologies (Hurl 2017).

Some professional organizations and accrediting bodies have emerged, however, for liberal professionals, market success as a social acknowledgement of the profession is important, compared to intermediate bodies (Maestripiere 2016). Yet, market success implies individual branding and reputation, therefore, social recognition from a professional perspective is fragile (Maestripiere 2016). However, this does not put business consulting professionals in a marginalized position but generates a substantial variety of elite management consultants and knowledge workers in precarious positions (Kitay \& Wright 2007).

\section{Research problem and questions}

For independent professionals, such as business consulting professionals, the dilemma of freedom and insecurity is embedded in their work (Osnowitz 2010). Standing (2018) analyzes this dilemma by mapping the independent professionals within the framework of the labor market and defining their position in relation to other groups. According to his categorization, the elite group serves the interests of billionaires; the salariat constitutes a shrinking number of people with labor-based security; the proletariat is the traditional working class in an increasingly weak position and the proficians are freelance professionals operating independently. He claims that precarious characteristics are embedded in most occupations and at most levels within corporations, although the categories are differentiated in accordance with income and position. The proficians, the independent professionals, are polarized in relation to employment terms, some enjoy high income and status in the market, others are exposed to underemployment and low income. This concept of polarization is supported by other researchers in this field (Gorman \& Sandefur 2011 and Kitay 2007).

The position of the research subject, namely, the middle-aged business consulting professionals, is not only shaped by their professional position but also by their age. Discrimination of middle-aged professionals has been recognized in international literature (Labour Market Spotlight 2003: Fig. 5: 117; Solem 2016; Viitasalo 2015). Among the patterns of discrimination, redundancy and organizational marginalization are applied (Platman 2004; Viitasalo 2015), which force or pull middle-aged workers 
out of full-time, permanent jobs (Platman 2004). Instead, flexible employment patterns, such as portfolio working, freelancing and consulting, are the alternative career for the middle-aged (Platman 2004). In addition to these 'push' factors, there exists 'pull' factors, which increase flexible employment among middle-aged professional employees. These 'pull' factors are self-expression, independence and control, related to selfemployment (Platman 2004).

This article focuses on the dilemma of insecurity and the professional freedom of the business consulting professionals. Despite their nonstandard employment, they are highly qualified professionals, meaning that they are endowed with the resources to act in the labor market, enjoy market access, negotiate with their clients or employer organizations and achieve their professional aspirations. Thus, their position and coping strategies imply not only precarious attributes in employment but also interesting and independent work. The study asks: how do freedom and insecurity express themselves in the business consulting work of middle-aged professionals and how do they cope with contingent work?

\section{Research methodology and data}

The interview data come from the Multiple job holding - practices and institutional frame - research project (2019-2021) at Tampere University, Work Research Centre. The study focuses on the changing patterns of employment and the sourcing of income from multiple assignments and contracts. The data collection focused on the professional labor force with a higher education degree and nonstandard employment patterns; the fields of culture and the arts, the media, the economy and society, engineering and training, were included in this study. Thus, the aim of the data collection was not to focus on the consulting profession. However, the business consultants emerged from the data as a particular professional group, which was different from the rest of the interviewees in relation to their position as service-oriented free professionals.

They were specialized in coaching, counselling, training, evaluation and development project management, and their professional work fell into the category of management consultancy in the official categorization carried out by the Statistical Office of Finland, which is adjusted to the European guidelines for statistical offices.

Consulting services cover a variety of fields, such as information and communication technology, accounting, legal service, architecture and other technical and employment services (Statistics Finland 2018). The position of business consultants in the labor market varies as regards this professional field with lawyers having the highest and employment services the lowest income; management consultancy positions rank between them (Statistics Finland 2020).

The data set includes 12 interviews, which were carried out from March to June 2019. Each interview lasted approximately 1 hour, one of which was carried out via telephone. The interviews were conducted in the workplace of the researcher or in a meeting room at the city library. Contact was made with the interviewees via personal networks and social media, and with the help of partners involved in the research project and employee trade unions. The interview data were collected, recorded, transcribed into text files and subsequently analyzed, using content analysis methodology (Silverman 2006).

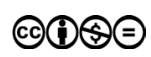


The study has undertaken actions to gain ethics approval from the Tampere University Advisory Board on Ethics for studies and activities that involved gathering data from individual participants. The study complied with applicable international, EU and national legislations for the protection of personal data.

The interview themes were loose, which allowed the interviewees to define the themes based on their own interests. The themes were employment and professional work, organization of tasks and schedules, previous career, family life, economic safety and future prospects.

The ages of the business consulting professionals varied from 45 to 65 years; two of them were men and 10 were women. They all had a degree from a higher education institution: half of them had a degree in economics; the other fields included social sciences, behavioral sciences and a combination of economics and cultural studies. The basic elements of the data are presented below:

Table I Background information of the interviewees: age and education

\begin{tabular}{lccccc}
\hline & Education & & & Total \\
\hline Age & Economics & $\begin{array}{c}\text { Social } \\
\text { sciences }\end{array}$ & $\begin{array}{c}\text { Combination:Economics } \\
\text { and cultural studies }\end{array}$ & $\begin{array}{c}\text { Educational } \\
\text { sciences }\end{array}$ \\
\hline $40-49$ & 2 & 1 & 1 & & 4 \\
\hline $50-59$ & 3 & 2 & & 2 & 5 \\
\hline $60-64$ & 1 & & 1 & 2 & 3 \\
\hline Total & 6 & 3 & & & 12 \\
\hline
\end{tabular}

The business consulting professionals sourced their income from multiple assignments and/or short-term employment contracts, and their situation varied periodically, regarding the number of tasks they juggled at any one time. The combinations of employment contracts and/or self-employment assignments were varied, and different patterns were applied throughout the phases of these professionals' careers. Most of the interviewees (i.e., 10 out of 12) had experiences of layoffs in their previous careers.

For this study, the business consulting professionals were divided into two groups, based on their main task, namely, coaching and development project management. Coaching included support for management in HR functions or strategic management. The development projects were arranged as follows: promoting or supporting the tasks of the work organization or launching new working methods or tasks, such as working on a plan aimed at funding applications for the organization or creating a service concept for clients of the organization.

Coaching was carried out as a self-employed activity, while the associated jobs were employment- or self-employment-based. Their associated managerial jobs were based on employment contracts, while the others, that is, training, therapeutic and development tasks, were based on self-employment, excluding one professional who had an employment contract.

The development project managers had short-term employment contracts while their associated jobs were based on self-employment. Their assignments or employment contracts were carried out on a short-term project basis or over a longer period, in parallel with other assignments or contracts. Their employment patterns in the spring of 2019 are presented in Table 2 . 
Table 2 Employment patterns and professional fields of the interviewees. Categorized by the main task and associated task

\begin{tabular}{lccc}
\hline Main task & Self-employed & $\begin{array}{c}\text { Short-term } \\
\text { employmentcontract }\end{array}$ & Total \\
\hline Coaching & 7 & 0 & 7 \\
\hline $\begin{array}{l}\text { Management of } \\
\text { development project }\end{array}$ & 0 & 5 & 5 \\
\hline Total & 7 & 5 & 12 \\
\hline
\end{tabular}

Associated tasks of those with coaching as their main task

\begin{tabular}{lccc}
\hline & Self-employed & $\begin{array}{c}\text { Short-term } \\
\text { employment contract }\end{array}$ & Total \\
\hline Management & 0 & 3 & 3 \\
\hline $\begin{array}{l}\text { Training, management of } \\
\text { development projects, } \\
\text { therapeutic task }\end{array}$ & 3 & 1 & 4 \\
\hline Total & 3 & 4 & 7 \\
\hline
\end{tabular}

Associated tasks of those who managed development projects as their main task

\begin{tabular}{lcc}
\hline Self-employed & $\begin{array}{c}\text { Short-term } \\
\text { employment contract }\end{array}$ & Total \\
\hline
\end{tabular}

Evaluation, training, counselling $\quad 3 \quad 2 \quad 5$

This group consisted mainly of women, but it was not possible to expand the analysis from a gender perspective for the following reasons: the consulting services seem to follow the typical segmentation by gender in relation to the business field; however, a more detailed analysis of professional employees' positions regarding their employment stability (employed and self-employed) and other indicators would have been necessary.

The data were categorized on the basis of the interview questions and the themes which emerged from the interview data. The main category was 'positive and negative multiple-task holding - patterns and coping', based on the following sub-categories: the nature of knowledge-based service work - interesting but restricted; the variety of employment patterns of combined self-employment and/or short-term employment; difficulties in terms of time management, but benefits related to similar or related tasks combination work; uncertainty in relation to contingent work. Discrimination related to age was not in the list of interview questions; however, the perspective of age featured in the category focused on the relatedness of recent and past careers.

The data were collected in Finland but the theoretical framework, the subject of the research and its related environment, in other words, the economy and the labor market can be generalized across national boundaries in Western countries to some extent. The increase in the service-oriented, non-institutionalized, professional labor force as a flexible labor market, is becoming common in Western countries as part of the global 
economy and the new transnational patterns of employment across the boundaries of nation states.

The analysis is as follows: first, flexibility is studied as a way of adjusting to the labor market and uncertainty related to careers and the future is explored; second, the multiplicity of tasks is analyzed and third, individual and collegial strategies are investigated. In the conclusion and discussion section, the results are considered in the framework of the post-industrial, service society and precarious employment.

\section{Flexibility in employment - the balance of uncertainty and freedom}

Flexibility was typical for the business consulting professionals; it was related to balancing the need for regular income and the desire for independence. Combining tasks was the business consulting professionals' method of reacting to diversified employment opportunities and terms. In addition, self-employment and employment as a salary earner were not mutually exclusive, nor did they even conflict. Even the long-term entrepreneurs sometimes accepted short-time employment contracts for economic reasons, although they expressed concerns relating to losing clients and being forced out of the market. Thus, the dilemma of entrepreneurial independence, as well as dependence on regular income was balanced with flexibility in employment. Flexibility was the obvious means of adjustment to the unstable position in the labor market.

Some business consulting professionals were more willing to work on a self-employment basis, others less so. Below are quotes from two interviewees, who were both selfemployed but had different mindsets. In the first quote, a coach with a long employment career in the banking sector describes her commitment to entrepreneurship, as well as the rationale for accepting reasonable employment contracts. She had had considerable experience of redundancies in previous workplaces, which had fostered her commitment to entrepreneurship:

'I am interested in short-time employment as a salary earner, in the sense that it has a clear start and end. I am not interested in regular jobs (in order to keep my own firm going). I left my job and started my own business, and I am not dependent on finding a permanent job'. (woman 50-59, coach)

Starting one's own business after a lengthy period of full-time employment was typical for those interviewed in the later stages of their career. They wanted to do 'something else' before retirement and had also experienced significant layoffs in their previous careers, either as a protagonist or as a colleague of someone who had been made redundant. The negative experience of redundancy was accompanied by tiredness and boredom in relation to the constant reorganization of personnel and tasks in their previous workplaces.

The desire for freedom as an entrepreneur was related to subjectivity, which became more pronounced after working in a large company, carrying out the same tasks for decades and experiencing the negative atmosphere related to redundancies. However, the converse of the independent position was the state of being exposed to underemployment, as well as irregular or low income, which sometimes led to a state 
of drifting between the opportunities and improbabilities of the different employment patterns.

The quote below is from a woman who has overseen development projects and evaluations as an entrepreneur. She regarded her self-employment as both positive, providing independence, and negative, since her income level was low and the terms for securing assignments were complicated. Her employment plans drifted between entrepreneurship and searching for a job, due to the time demands of the assignments and the fact that searching for a job was challenging:

A couple of years ago, I had an employment contract as a manager on a development project and it was enjoyable. I thought that I should no longer try to make my living as an entrepreneur, as it leads to a low income. I am afraid that I may never get a full-time employment contract now. Therefore, I should make the decision to leave self-employment and try to get a job, so that my drifting between jobs will stop. However, it would be silly not to join a nice entrepreneurs' network, find nice assignments and meet pleasant people. And the assignments may lead to new assignments, if they are done well. (woman, 45-49, development project manager)

Some business consulting professionals reported age-specific discrimination, although this subject was not specifically targeted in the interviews. For example, a male consultant in his fifties claimed that he no longer receives calls for recruitment interviews and a female manager of development projects in her sixties, reported discrimination relating to redundancy regulations. She maintained that after being laid-off for economic reasons, she was not offered any available positions by her employer, which constituted a juridical infraction. Age-specific discrimination cannot be verified here, but the analysis also reveals precarious attributes in the careers of middle-aged professionals. In addition, the polarization into stable and unstable positions tends to be institutionalized and movement to more stable positions in this case may be difficult.

The contingent nature of the business consultancy profession related to uncertainty about the future, as the consultants were dependent on the demand for their services and were exposed to market trends. Most of them had regular sources of income, which slightly relieved the pressure of searching for new income sources. For example, some of them participated in tenders on consulting in public sector or nonprofit private sector organizations, which could provide them an assignment for many years. The regular sources were related to networking with clients and employers, which is a crucial way of staying in the market (Barley \& Kunda 2004). Thus, they combined regular and on-demand jobs. For staying in the market, they had to adopt new consulting concepts and branding.

Uncertainty of income was also related to the problems regarding social security systems in society. Those with the status of entrepreneur were not entitled to unemployment benefits. Those with a combination of a part-time entrepreneurship and a salaried position, feared they would be categorized as entrepreneurs with no access to benefits. Their fears were justified for following reason: in Finland, the implementation of regulations dealing with unemployment benefits in nonstandard employment is ambiguous and it varies from one employment office to another (Honkanen 2018). Thus, the precariousness is not only related to unstable positions and income, but also to exclusion from the systems of the welfare state, which should provide security for citizens. The 
uneven implementation of regulations regarding the access to unemployment benefits, is part of the insecurity problem, since planning one's future is based on regular income and trust of the institutions in society.

Uncertainty was expressed in all the interviews: the consultants drifted between fear and self-trust. For some of them, the fear was under control, but others felt more depressed. The first quote below describes the controlled approach and the latter a more depressed view, with no hope for a better future:

\footnotetext{
Being an entrepreneur is based on securing sufficient assignments. Nowadays, I trust myself and I think I will get more of them (compared to the situation at the beginning of the entrepreneurship). I certainly do have phases of despair, but my husband and my friends have supported me. (woman, 50-59, coach)
}

I have periods of depression, during which time I think that this is not going to work and the assignments will continue to be short-term in the future. And sometimes, I know that there will be nothing for me for a month or two. (woman, 40-49, development project manager)

Thus, insecurity was constantly present in their personal and professional lives, although the pressures varied from consciousness of insecurity to the fear of economic breakdown. For the business consulting professionals, insecurity was embedded in their employment and careers, which were characterized by precariousness (Lorey 2015; Standing 2014). The studies in this field report that the precarious employment of the qualified labor force is typical in the case of young people searching for an alternative life-style, as well as artists and those working in media or the creative industries. Middle-aged business consulting professionals have not been studied as one of these groups, despite the similarities in terms of employment and insecurity. However, following Standing's (2014) categorization, business consulting professionals are 'proficians', whose tasks resemble those within interim management but without the commanding, regular salary and stable employment position. Their position is representative of the views of Lorey (2015) and Standing (2014), for these authors emphasize the nature of precariousness as being scattered among different professions and positions in the labor market and society.

\section{Coping with the multiplicity of tasks}

The coping strategies of the business consulting professionals were based on flexibility: constant searching for new assignments and contracts, mastering many contemporary projects, adjusting their services to the demands of the market and networking with other business consulting professionals.

To guarantee their income, the business consulting professionals had to search constantly for new assignments and employment contracts even when they were working full-time on ongoing projects. As the tasks of the business consulting professionals were often similar or related, this decreased the available workload of assignments or contracts. The similarity of the tasks was content-related, such as knowledge base or working methods. For example, teaching HR management and acting as a coach in HR 
are mutually related tasks with regard to the content of the work. Only one of the interviewees had a combination of two different tasks:

They (assignments and employment contracts) originate from the same source, which is (language) training and testing. I carry out the teaching at my workplace and utilize the related planning and experience I have gained from the training service provided by my enterprise. It is really motivating. (woman, 60-64, development project manager)

However, all the tasks had their own specific time schedules, and coping with different employment contracts and assignments was a challenge. This result is supported by studies on freelancers and independent contractors, which also report increasing stress as a consequence of the multiplicity of tasks (Gallagher 2008). The assignments and tasks sometimes overlapped, despite the agreed schedules, as the process of anticipated and nonanticipated phases did not always follow these schedules. In addition, social commitments to clients sometimes transgressed the limits of the agreed service. Social commitments refer to clients' telephone calls and internet-based messages, which were received outside the agreed time schedule. The phenomenon is recognized as 'client colonization' by Gold and Mustafa (2013). Digital information and communication technology sometimes exposed the professionals to having to work unlimited hours:

I tried a part-time job, in addition to my coaching duties as an entrepreneur, but my time was hard to manage. I could not divide my time amongst my duties. And the part-time job stopped being part-time, it was more like a full-time job. (man, 60-64, coach)

Sometimes, all the assignments required full-time attention at the same time, which resulted in a heavy workload. In addition to the tasks, having to submit applications and tender bids led to a sense of having to rush and resulted in frustration if the outcome was negative:

You must put a lot of work into tenders if you want to win. Nobody pays anything for your work if you lose out to the competition. And it is a lot of work in total. At least, you must be interested and inspired about the assignment. (woman, 40-49, development project manager)

The workload was, in general, reported to be under control, but due to unanticipated processes, it sometimes resulted in stress. Increases in workload were typical during the course of projects with strict deadlines.

Constant attentiveness for market demands and individualized time management due to the organizationally scattered tasks, dominated the work of the business consulting professionals. They struggled to control their income and duties, as they were exposed to the external demands from the market, clients and employers. The individualized struggle over controlling one's schedule, in addition to future income, was related to their profession, in which the risks of employment and income are embedded. Subjectivity is based on their position of being exposed to the market and striving for individual freedom. 


\section{Individual and collegial strategies}

The interviewees sourced their expertise from their former careers, which had provided them with the relevant competences for consulting work. They described their service orientation in terms of a task, based on their expertise and adjusted to the needs of their clients. This expertise was a mixture of professional competence, sourced from their previous careers and education, expertise acquired from recent assignments, training and sometimes peer learning via their networks. Service was the framework for the design of their professional expertise, which demanded adjustment in relation to the market. A male coach described the transformation of his employment from previous managerial positions to coaching, by referring to the differences between paid employment and self-employment in consulting:

In a way, my consulting work is similar to my career over the last 20 years. I have been a manager of economic and business functions and a chief executive officer. My competences are economics, business strategy and management. I work now in these fields, but as a service provider. The tempo is much higher. There is more variation, but I exploit my core competences. (man, 40-49, coach)

However, the services of business consulting professionals are exposed to external control in the sense that the client controls the purpose of the service, although the consulting professional has control over the field-specific knowledge and methods. The external control over the purpose of the professional work may conflict with the content of the services. In the following quote is an example of a client defining the purpose of professional services in a different, slightly derogatory way. An ironic comment was made by the coach, whose idea of coaching was ignored by his client:

The sessions of personnel coaching are nowadays rather short, although coaching should be a long process. They (the managers of the client firms) say 'go there for three or four sessions and try to do something'. That is an approach which does not recognize the perspective of development in work. They regard it rather as a method to calm down their personnel. (man, 60-64, coach)

Despite this, they were committed to their professional work and wanted to develop their profession with individual aspirations and with their professional networks. Tight schedules and short-term tasks limited the opportunity to develop competence, which can only be achieved when there are uninterrupted processes in planning and time to reflect on the service. Some senior business consulting entrepreneurs wished for longterm employment so that they could develop their expertise. This aspiration was also related to tackling the increasing insecurity relating to market competition, for there was a risk of dropping out of the market if their professional service was regarded as outdated. One of the coaches expressed her wishes for a longer process of developing her business as follows:

I occasionally think that I want to do more effective work, work on a bigger scale in the context of a work organization. Now the significance of my work is to support people's well-being. (...) I have a dream to write or do something like that. (woman, 50-59, coach) 
In particular, the coaches collaborated with their colleagues to promote their business opportunities. The collaboration ranged from casual interaction among peers to institutionalized practices and patterns, with which they strove to enhance the professional status of the group and promote the business. One of the coaches describes her professional network and the related institutionalized patterns, which even implies the patterns of business companies:

We have shared business premises and expenses, in which we have all participated. I very much value collaboration with the other entrepreneurs, as it means I am not alone as an entrepreneur. (woman, 50-60, coach)

Within the institutionalized networks of consulting professionals were aspirations to promote the status of this professional group. Personnel coaches, in particular, embraced the institutionalization of their competences, ethical codes, training community and pricing practices. However, they recognized the limited effectiveness of their aim, as they sold their services in deregulated markets, which do not favor institutionalized, professional patterns. In addition, collaboration was related to mutual competition. The following quote describes the competition related to collaboration and the associated negative consequences:

Yes, there is competitiveness. I face competition (from my colleague) as we have similar expertise in coaching. (...) You have to earn your assignments all the time and it shapes your personality in such a way that you start to sell yourself. I have recognized that I have become one of them, a besserwisser, always saying how it is. (woman, 50-59, coach)

Competition is embedded in the subjectivity of free market professionals but searching for new assignments and jobs through networks, is a practice typical of the market (Schaff 2016). The institutionalized networks of professional collaboration have striven to regulate the relations among the members being exposed to competition in the markets. Despite this collective action, competition has followed the logic of subjectivity with individualized risk in the business.

The business consulting professionals applied individual and collective strategies, typical of institutionalized professions, which were incompatible. However, they were aware of this and strove to control the tension between them.

\section{Limits of the study}

Data relating to the research were limited with 12 interviews. Thus, the analyses did not produce detailed interpretations. The subject of research, that of business consulting professionals with multiple income sources, has not been focused on in sociological research, which limits the opportunities for comparison and enhancing the validity of research.

\section{Conclusions and discussion}

The research focuses on how middle-aged business consulting professionals have striven to balance their position between insecurity and the desire for freedom with flexibility 
in the labor market. These professionals have pursued individual and collective coping strategies, which were not necessarily compatible.

The theoretical approach of the analysis was based on the post-industrial service society and precariousness, which both deal with the deregulation of the labor market. The approach of the post-industrial service society studies the reshaping of professional work into service-oriented expert work and its associated contingent employment. The theories of precariousness discuss insecurity in relation to the decline of employment terms and retarded welfare institutions in society. This approach has been criticized for being all-embracing, in other words, striving to explain too wide a variety of trends in society (Jokinen 2018). In addition, precarious employment, that is, nonstandard and unstable employment, is not a new phenomenon (Lehto \& Sutela 2008).

However, the approach of precariousness is discussed in a new cultural, political, social and economic environment, the post-industrial society, and for this research, it provides a framework for understanding the position and coping strategies of the qualified professional labor force. The labor market position of the qualified professional labor force has changed in respect of their employment terms. Since the economic recession of the 1990s, a deregulation of the labor market and outsourcing, related to increasing service-oriented professional positions, have taken place. In addition, the institutional shelter for unemployment and underemployment has become vague, as the welfare institutions are built for the industrial era and do not recognize the variety of employment patterns and their associated vulnerability. Therefore, the fact that the free market professionals are exposed to this vulnerability, is related to their individualized insecurity and risk.

Precariousness penetrates employment in various ways, which makes the division of safe, full-time employment and self-employment less clear. The business consulting professionals' experiences of layoffs from previous employer organizations or suffering the consequences of redundancies in the workplace render the division between full-time employment and contingent work ambiguous in relation to precariousness. In this study, Guy Standing's (2014) approach was applied, for his conceptualizing study illuminates the matrix position of qualified professionals. In other words, interesting and independent work in qualified labor market positions have either constant or occasionally precarious characteristics. The consultants were highly qualified professionals with interesting work, but, as service providers for short time demands, they were exposed to external powers in many senses, particularly economically and professionally.

In addition to the work of Standing (2014), Lorey's (2015) theoretical work is applied here, because Standing's conceptualizing study does not examine in great detail the coping strategies of those operating in a precarious position. Lorey's (2015) idea in relation to precariousness deals with micro-level and society-level interaction and the ability of human beings coping within their environment is crucial in this sense. Subjectivity and individualized risk are typical for the subject of this research and their coping strategies are shaped within this frame. For the consultants, the sense of freedom was accompanied by flexible adaptation to market demands. Subjectivity was fostered, in particular, among those with previous careers in large corporations, which emphasizes the significance of a professional mindset and a desire for self-realization.

The business consultant professionals also applied collective strategies, but the impact of these strategies remained relatively minor, due to the professional profile of these professionals as free market experts with an individualized strategy in the 
deregulated labor market. The individualized strategies, related to the deregulated market, were at variance with the collective strategy. However, even free market professionals tend to network and promote collaboration for shared interests, which also implies a collective mindset, at least to some extent. Thus, individualized 'professioning' may not reject collective action, but there is a constant tension to address.

This study contributes to the theory of precariousness being embedded in the contemporary labor market, for it reveals precarious characteristics relating to positions which are usually not considered unstable or insecure. Therefore, this result also calls for further sociological research work into free professionals. This is related to the critical remarks on the all-embracing nature of the theory, which requires additional theoretical work to increase its analytical power when studying detailed complexities in employment.

\section{Acknowledgement}

The research project has been funded by the Finnish Work Environment Fund and the member organizations of the steering group: employee trade unions (Akava The Confederation of Unions for Professional and Managerial Staff in Finland and five Affiliates and TEME from The Central Organisation of Finnish Trade Unions) and the insurance companies TELA and Turva.

\section{References}

Ashforth, B., Kreiner G. \& Fugate M. (2000). All in a day's work: Boundaries and micro role transitions, Academy of Management Review 25(3): 472-491. doi: http://dx.doi.org/ 10.5465/amr.2000.3363315.

Atkinson, W. (2007). Beck, individualization, and the death of class: A critique, The British Journal of Sociology 58(3): 349-366. doi: https://doi.org/10.1111/j.1468-4446. 2007.00155.x.

Barley, S. R. \& Kunda, G. (2004). Gurus, Hired Guns, and Warm Bodies, Princeton NJ: Princeton University Press.

Barley, S. R. \& Kunda, G. (2006). Contracting: A new form of professional practice, Academy of Management Perspectives 20: 45-66. doi: https://doi.org/10.5465/ amp.2006.19873409.

Bieler, A., Lindberg, I. \& Sauerborn, W. (2010). After 30 years of deadlock: Labour's possible strategies in the new global order, Globalizations 7(1-2): 247-260. doi: https://doi. org/10.1080/14747731003593653.

Boje, T. (2003). Towards a post-industrial service society, in Furåker, B. (ed.) Post-industrial Labour Markets: Profiles of North America and Scandinavia, London, New York: Taylor and Frances Group, Routledge: 124-146.

Boje, T. \& Furåker, B. (2003). Introduction. Labour markets under intensified competition, in Furåker, B. (ed.) Post-industrial Labour Markets: Profiles of North America and Scandinavia, London, New York: Taylor and Frances Group, Routledge: 1-16.

Boje, T. \& Grönlund, A. (2003). Flexibility and employment in security, in Furåker, B. (ed.) Post-industrial Labour Markets: Profiles of North America and Scandinavia, London, New York: Taylor and Frances Group, Routledge: 186-212. 
Brint, S. (2001). Professionals and the knowledge economy: Rethinking the theory of post-industrial society, Current Sociology 49(4): 101-132. doi: https://oi.org/ 10.1177/0011392101049004007.

Browing, H. \& Singelmann, J. (1978). The transformation of the U.S. labor force, Politics and Society 8(3-4): 481-509.

Clark, S. (2000). Work/family border theory: A new theory of work/family balance, Human Relations 53(6): 747-770. doi: http://dx.doi.org/10.1177/0018726700536001.

Maestripiere, L. (2016). " "Professionalization at work: The case of Italian management consultants. Ephemera: Theory \& Politics in Organization 16:2, 31-52.

Eurofound (2018). Labour market change. Non-standard forms of employment: Recent trends and future prospects. European Foundation for the Improvement of Living and Working Conditions. Eurofound, Dublin. Available at: https://www.eurofound.europa.eu/sites/ default/files/ef publication/field ef document/ef1746en.pdf (Accessed August 2019).

Gallagher, D. G. (2008). Independent contracting: finding a balance between flexibility and individual well-being, in Naswell, K., Hellgren, J. and Sverke, M. (Eds), The Individual in the Changing Working Life, Cambridge University Press, Cambridge, pp. 108-125.

Gold, M. and Mustafa, M. (2013). 'Work always wins': client colonisation, time management and the anxieties of connected freelancers, New Technology, Work and Employment 28(3): 197-211.

Gorman, E. \& Sandefur, R (2011). 'Golden Age,' “Quiescence, and Revival. How the Sociology of Professions Became the Study of Knowledge-Based Work, Work and Occupations 38 (3): 275-302. doi: https://doi.org/10.1177/0730888411417565.

Harvey, D. (2005). A Brief History of Neo-liberalism, Oxford: Oxford University Press.

Honkanen, P. (2018). Sosiaaliturva ja verotus joustotyön aikakaudella (Social security and tax systems in the era of flexible labour), in Suoranta, A. \& Leinikki, S. (eds.) Rapautuvan palkkatyön yhteiskunta (Crumbling labour society), Tallinn: Vastapaino, 91-119.

Hurl, C. (2017). (Dis)Assembling policy pipelines: unpacking the work of management consultants at public meetings, Geographica Helvetica 72(2): 183-195. doi: http://dx.doi:. org/10.5194/gh-72-183-2017.

Kalleberg, A. \& Mouw, T. (2018). Occupations, organizations, and intragenerational career mobility, Annual Review of Sociology 44: 283-303. doi: https://doi.org/10.1146/ annurev-soc-073117-041249.

Kitay, J. \& Wright, C. (2007). From prophets to profits: The occupational rhetoric of MCs, Human Relations 60(11): 1613-1640.

Kouvo, A. \& Kankainen, T. (2009) Sosiaalista pääomaa rakentamassa vai purkamassa? Suomalaiset hyvinvointipalvelut ja yleistynyt luottamus. (Building or eroding social capital? Finnish welfare state institutions and generalized trust). Yhteiskuntapolitiikka 74 YHTEISKUNTAPOLITIIKKA 74(6): 585-603.

Lehto, A.-M. \& Sutela, H. (2008). Työolojen kolme vuosikymmentä. Työolotutkimusten tuloksia 1977-2008. (Three decades of employment conditions. Research results 1977-2008), Helsinki: Multiprint.

Lorey, I. (2015). State of iinsecurity: Government of the precarious, London: Verso Books.

Maestripiere, L. (2016). Professionalization at work: The case of Italian management consultants, Ephemera: Theory \& Politics in Organization 16(2): 31-52.

Neal, M. \& Morgan, J. (2000). The professionalization of everyone? A comparative study of the development of the professions in the United Kingdom and Germany, European Sociological Review 16(1): 9-26. doi: https://doi.org/10.1093/esr/16.1.9.

McKenna, C. (2006). The World's Newest Profession, Cambridge, UK: Cambridge University.

OECD (2018). Job Creation and Local Economic Development 2018. Preparing for the Future of Work, Paris: OECD Publishing. doi: http://dx.doi.org/10.1787/9789264305342-en. 
Osnowitz, D. (2010). Freelancing Expertise: Contract Professionals in the New Economy, Ithaca, NY: Cornell University Press.

Pfeffer, J. (1994). Competitive Advantage Through People: Unleashing the Power of the Work Force, Boston, MA: Harvard Business School Press.

Platman, K. (2004). 'Portfolio careers' and the search for flexibility in later life. Work Employment \& Society, 18(3): 573-599. doi: https://doi.org/10.1177/0950017004045551.

Pollitt, C. \& Bouchaert, G. (2004). Public Management Reform. A Comparative Analysis Into The Age of Austerity, Oxford: Oxford University Press.

Pouliakas, K. (2017). Multiple job-holding: Career pathway or dire straits? Moonlighting responds to economic needs, but can generate new skills and careers. IZA World of Labour. Available at: https://wol.iza.org/articles/multiple-job-holding-career-pathwayor-dire-straits/long (Accessed January 2020).

Reynolds, R. \& Renzulli, L. A. (2005). Economic Freedom or Self-imposed Strife: Work-Life Conflict, Gender, and Self-Employment, Entrepreneurship. Emerald Group Publishing Limited. doi: http://dx.doi.org/10.1016/S0277-2833(05)15003-1.

Statistics Finland. (2020). PxWeb Database: information on average income retrieved. Available at: http://pxnet2.stat.fi/PXWeb/pxweb/fi/StatFin/StatFin pal pra/statfin pra pxt 11z4.px/table/tableViewLayout1/ (Accessed April 2020).

Sutela, H. \& Pärnänen, A. (2018). Yrittäjät Suomessa 2017. Tilastokeskus. Available at: http://www.stat.fi/tup/julkaisut/tiedostot/julkaisuluettelo/ytym 201700201821465 net.pdf (Accessed April 2020).

Statistics Finland (2018). Management consultancy services clearly growing in 2017. 3 October 2018. Available at: https:/www.stat.fi/til/palhy/2017/palhy 2017 2018-10-03 tie 001 en.html (Accessed September 2019).

Solem, P. E. 2016. Ageism and age discrimination in working life. Nordic Psychology 68(3): 160-175. doi: https://doi.org/10.1080/19012276.2015.1095650.

Standing, G. (2018). The precariat: Today's transformative class? Development (61): 115-121. doi: https://doi.org/10.1057/s41301-018-0182-5.

Standing, G. (2014). The Precariat: The New Dangerous Class, Bloomsbury Publishing PLC.

Thelen, K. (2012). Varieties of capitalism. Trajectories of liberalization and the new politics of social solidarity, The Annual Review of Political Science 15: 137-159. doi: https://doi. org/10.1146/annurev-polisci-070110-122959.

Vallas, S. P. (2017). Emerging Conceptions of Work, Management and the Labor Market, Emerald Publishing Limited.

Vallas, S. P. \& Cummins, E. R. (2015). Personal branding and identity norms in the popular business press: Enterprise culture in an age of precarity, Organization Studies 36(3): 293-319. doi: https://doi.org/10.1177/0170840614563741.

Veggeland, N. (2015). The politics of outsourcing in Western Europe, Current Politics \& Economics of Europe 26(1): 65-91.

Viitasalo, N. (2015). Varttuneet ja ikäsyrjintä työelämässä. (Discrimination of older workers in working life). Academic Dissertation, Tampere University Press. https://trepo.tuni.fil handle/10024/98155. 